\title{
Diagnosis of respiratory epithelial clearance abnormality in patients suffering from chemo-resistant pulmonary tuberculosis with comorbidity of bronchial mucosa
}

\author{
0. M. Raznatovska, V. M. Khlystun \\ Zaporizhzhia State Medical University, Ukraine
}

Respiratory epithelial clearance timely and early disorder diagnosis in patients suffering from chemo-resistant pulmonary tuberculosis (CRPTB) concomitant pathology of the bronchial mucosa is an actual problem of modern phthisiology, the solution of which will allow the timely application of rational correction, which will increase the effectiveness of this category treatment among patients.

Objective is to investigate the nature and features of respiratory epithelial clearance disorders among patients suffering from CRPTB with comorbidity of the bronchi mucous membrane by using the developed method of these disorders diagnosis.

Materials and methods. The respiratory epithelial clearance state diagnosis was carried out among 133 patients with CRPTB at the beginning of the intensive phase of antimycobacterial therapy during fibrobronchoscopy, provided there is a concomitant specific pathology of the mucous membrane (including its combination with non-specific endobronchitis). Average age of patients was $36.5 \pm 1.1$ years old. There were $89(66.9 \%)$ men and $44(33.1 \%)$ women. The tracheobronchial tree diagnostic fibrobronchoscopy with further study of the respiratory epithelial clearance condition among patients suffering from CRPTB was carried out by V. M. Khlystun at Phthisiology and Pulmonology Department of Zaporizhzhia State Medical University in $\mathrm{Cl}$ Zaporizhzhia Regional Antituberculous Clinical Dispensary. Criteria of patients including into the research: existence of resistance of tuberculosis mycobacteria to anti-mycobacterial drugs in patients with new and repeated cases of tuberculosis, existence of pathology of the mucosa of bronchi confirmed during fiberoptic bronchoscopy. Serious associated diseases (HIV infection/AIDS, diabetes mellitus, etc.) were criteria of exception. The condition of bronchial mucosa was studied under narcotic anaesthesia by fiberoptic bronchoscopes of Olympus (Japan). Pathology of a bronchial tree was described according to classification by M. V. Shesterina, A. N. Kalyuk (1975). Results of the research are processed by modern methods of the analysis using the personal computer with the statistical package Statistica ${ }^{\circledR}$ for Windows 6.0 license program (StatSoft Inc., No. AXXR712 D833214FAN5).

Results. There were respiratory epithelial clearance disturbances in $94.7 \%$, which predominate with the $1^{\text {st }}$ and $2^{\text {nd }}$ stages of mucociliary inefficiency (51.1\% and $37.6 \%$ ). There was mucociliary inefficiency dependence on the bronchi mucous membrane pathology nature: the incidence of respiratory epithelial clearance in patients with concomitant bronchial tuberculosis in combination with the nonspecific purulent endobronchitis is 2.4 times higher than in those with concomitant bronchial tuberculosis only (70.7\% vs $29.3 \%)$. The association of nonspecific purulent endobronchitis with concomitant bronchial tuberculosis leads to an increase in the mucociliary inefficiency degree of severity, due to its diffuse localization, where it is diagnosed more often than in the limited one, thus, mucociliary inefficiency of the $2^{\text {nd }}$ stage of severity ( $64.9 \%$ vs $24.6 \%$, is 2.6 times more $(64.9 \%$ vs $24.6 \%)$ and 4.6 times more in the $3^{\text {rd }}$ stage $(16.2 \%$ vs $3.5 \%)$.

Conclusions. The proposed method for the diagnosis of mucociliary inefficiency disorders among patients suffering from CRPTB with bronchial mucosa concomitant pathology allows to diagnose mucociliary inefficiency and mucociliary inefficiency dependence on the bronchi mucous membrane pathology nature.

\section{Аіагностика порушень мукоцияіарного транспорту у хворих на хіміорезистентний туберкульоз мегень із супутньою патологією слизової оболонки бронхів}

\section{О. М. Разнатовська, В. М. Хлистун}

Своєчасна та рання діагностика порушень мукоциліарного транспорту у хворих на хіміорезистентний туберкульоз (ХРТБ) легень із супутньою патологією слизової оболонки бронхів - актуальна проблема сучасної фртизіатрії, вирішення якої дасть змогу своєчасно застосувати раціональну корекцію, що підвищить ефективність лікування таких хворих.

Мета роботи - вивчити характер та особливості порушень мукоциліарного транспорту у хворих на ХРТБ легень із супутньою патологією слизової оболонки бронхів шляхом застосування розробленого способу діагностики цих порушень.

Матеріали та методи. Діагностику стану мукоциліарного транспорту виконали у 133 хворих на ХРТБ легень на початку інтенсивної фази антимікобактеріальної терапії під час фібробронхоскопії за умови наявності супутньої специффічної патології слизової оболонки (у тому числі її поєднання з неспецифічним ендобронхітом). Середній вік хворих становив $36,5 \pm 1,1$ року. Чоловіків було 89 (66,9 \%), жінок - 44 (33,1 \%). Діагностичну фібробронхоскопію трахеобронхіального дерева з наступним вивченням стану мукоциліарного транспорту у хворих на ХРТБ легень виконали на клінічній базі кафедри фтизіатрії і пульмонології ЗДМУ в КУ «Запорізький обласний протитуберкульозний диспансер» власноруч В. М. Хлистуном. Критерії залучення пацієнтів у дослідження: наявність резистентності мікобактерій туберкульозу до антимікобактеріальних препаратів, наявність патології слизової оболонки бронхів, що підтверджена під час фібробронхоскопії. Критерії виключення: тяжкі супутні захворювання (ВІЛ-інфекція/СНІД, цукровий діабет тощо). Стан слизової

Ключові слова: бронхоскопія, трахеобронхіальне Аерево, слизова оболонка, хіміорезистентний туберкульоз, мукоциліарна транспортна система.

Патологія. - 2018. T. 15, № 1(42). -

C. $77-80$ 
оболонки бронхів вивчали під наркозною анестезією фібробронхоскопом фірми «Olympus» (Японія). Патологію бронхіального дерева описували за класифікацією М. В. Шестериної, А. Н. Калюк (1975). Результати дослідження опрацювали сучасними методами аналізу на персональному комп'ютері з використанням статистичного пакета ліцензійної програми Statistica ${ }^{\circledR}$ for Windows 6.0 (StatSoft Inc., № AXXR712 D833214FAN5).

Результати. Запропонований спосіб діагностики порушень мукоциліарного транспорту у хворих на ХРТБ легень із супутньою патологією слизової оболонки бронхів шляхом простого та швидкого у використанні методу, без суттєвих матеріальних і часових витрат, залучення додаткового спеціально навченого персоналу, безпечного для здоров'я пацієнта, безпосереднього ендобронхіального введення у бронхи гепаринізованої крові обстежуваного хворого під час фібробронхоскопії, без побічних реакцій та із запобіганням інффікуванню персоналу хіміорезистентими штамами мікобактерій туберкульозу дав змогу виявити порушення мукоциліарного транспорту в 94,7 \%, які були переважно з I та II ступенями мукоциліарної недостатності (51,1 \% і 37,6 \% відповідно). Встановили залежність мукоциліарної недостатності від характеру патології слизової оболонки бронхів: частота порушення мукоциліарної недостатності у хворих із супутнім туберкульозом бронхів у поєднанні з неспецифічним гнійним ендобронхітом вища у 2,4 раза, ніж в осіб із супутнім лише туберкульозом бронха (70,7 \% проти 29,3\%). Приєднання неспецифічного гнійного ендобронхіту до супутнього туберкульозу бронха призводить до збільшення ступеня тяжкості мукоциліарної недостатності шляхом дифузної його локалізації, де у 2,6 раза частіше діагностують, ніж при обмеженому, мукоциліарну недостатність ІІ ступеня тяжкості (64,9 \% проти 24,6 \%), у 4,6 раза - III ступеня (16,2 \% проти 3,5 \%).

Висновки. Запропонований спосіб діагностики порушень мукоциліарного транспорту у хворих на ХРТБ легень із супутньою патологією слизової оболонки бронхів дає змогу діагностувати порушення мукоциліарного транспорту та визначити залежність мукоциліарної недостатності від характеру патології слизової оболонки бронхів.

\section{Киючевые слова:}

бронхоскопия,

трахеоброн-

хиальное дерево,

слизистая

оболочка,

химиорезистентный

туберкулез,

мукоцилиарная

транспортная

система.

Патология. - 2018. -

T. 15, № 1(42). -

C. $77-80$

\section{Аиагностика нарушений мукоцикиарного транспорта у больных химиорезистентным туберкулезом легких с сопутствующей патологией слизистой оболочки бронхов}

\section{Е. Н. Разнатовская, В. Н. Хлыстун}

Своевременная и ранняя диагностика нарушений мукоцилиарного транспорта у больных химиорезистентным туберкулезом (ХРТБ) легких с сопутствующей патологией слизистой оболочки бронхов является актуальной проблемой современной фртизиатрии, решение которой позволит своевременно применить рациональную коррекцию, что повысит эффрективность лечения данной категории больных.

Цель работы - изучить характер и особенности нарушений мукоцилиарного транспорта у больных ХРТБ легких с сопутствующей патологией слизистой оболочки бронхов путем применения разработанного способа диагностики этих нарушений.

Материалы и методы. Диагностику состояния мукоцилиарного транспорта провели у 133 больных ХРТБ легких в начале интенсивной фазы антимикобактериальной терапии во время фибробронхоскопии при наличии сопутствующей специфической патологии слизистой оболочки (в том числе ее сочетания с неспецифическим эндобронхитом). Средний возраст больных составил 36,5 +1,1 года. Мужчин было 89 (66,9 \%), женщин - 44 (33,1 \%). Диагностическая фиббробронхоскопия трахеобронхиального дерева с последующим изучением состояния мукоцилиарного транспорта у больных ХРТБ легких проведена на клинической базе кафедры фртизиатрии и пульмонологии ЗГМУ в КУ «Запорожский областной противотуберкулезный диспансер» собственноручно В. Н. Хлыстуном. Критерии включения пациентов в исследование: наличие резистентности микобактерий туберкулеза к антимикобактериальным препаратам, наличие патологии слизистой оболочки бронхов, подтвержденной при фибробронхоскопии. Критерии исключения: тяжелые сопутствующие заболевания (ВИЧ-инфекция/СПИД, сахарный диабет и др.). Состояние слизистой оболочки бронхов изучали под наркозной анестезией фибробронхоскопом фрирмы «Olympus» (Япония). Патологию бронхиального дерева описывали по классификации М. В. Шестериной, А. Н. Калюк (1975). Результаты исследования обработаны современными методами анализа на персональном компьютере с использованием статистического пакета лицензионной программы Statistica ${ }^{\circledR}$ for Windows 6.0 (StatSoft Inc., № AXXR712 D833214FAN5).

Результаты. Предложенный способ диагностики нарушений мукоцилиарного транспорта у больных ХРТБ легких с сопутствующей патологией слизистой оболочки бронхов путем простого и быстрого в использовании метода, без существенных материальных и временных затрат, привлечения дополнительного специально обученного персонала, безопасного для здоровья пациента, непосредственного эндобронхиального введения в бронхи гепаринизированной крови обследуемого больного во время проведения фибробронхоскопии, без побочных реакций и с предупреждением инфицирования персонала химиорезистентными штаммами микобактерий туберкулеза позволило диагностировать нарушение мукоцилиарного транспорта в 94,7 \%, преимущественно с I и II степенями мукоцилиарной недостаточности (51,1 \% и 37,6 \% соответственно). Установлена зависимость мукоцилиарной недостаточности от характера патологии слизистой оболочки бронхов: частота нарушения мукоцилиарного транспорта у больных с сопутствующим туберкулезом бронхов в сочетании с неспецифическим гнойным эндобронхитом выше в 2,4 раза, чем у лиц с сопутствующим только туберкулезом бронха (70,7 \% против 29,3%). Присоединение неспецифического гнойного эндобронхита к сопутствующему туберкулезу бронха приводит к нарастанию степени тяжести мукоцилиарной недостаточности за счет диффузной его локализации, где в 2,6 раза чаще диагностируют, чем при ограниченном, мукоцилиарную недостаточность II степени тяжести (64,9\% против 24,6 \%), в 4,6 раза - III степени (16,2\% против 3,5\%).

Выводы. Предложенный способ диагностики нарушений мукоцилиарного транспорта у больных ХРТБ легких с сопутствующей патологией слизистой оболочки бронхов позволяет диагностировать нарушения мукоцилиарного транспорта и установить зависимость мукоцилиарной недостаточности от характера патологии слизистой оболочки бронхов. 
One of the important parts of the local respiratory protection system is the mucociliary system [1,2]. It provides purification of the tracheobronchial system from damaging factors and infectious agents, the action of which is the direct cause of disturbance of the bronchi drainage function - respiratory epithelial clearance (REC) [3]. As far as it is known, one of the pathogenetic mechanisms of bronchopulmonary diseases, including pulmonary tuberculosis, is precisely the violation of the bronchi drainage function $[4,7]$.

As of today, there are sufficient methods for diagnosis of REC disorders [5,6], but there are no data on the diagnosis of REC disorders in patients suffering from chemo-resistant pulmonary tuberculosis (CRPTB) with concomitant pathology of the bronchial mucosa, which led to the search for an adequate method that would be simple and fast in use, minimally safe for a patient, and which would not cause significant material costs or specially trained personnel.

Thus, REC timely and early disorder diagnosis in patients suffering from CRPTB concomitant pathology of the bronchial mucosa is an actual problem of modern phthisiology, the solution of which will allow the timely application of rational correction, which will increase the effectiveness of this category treatment among patients.

\section{The purpose of the research}

To investigate the nature and features of REC disorders among patients suffering from CRPTB with comorbidity of the bronchi mucous membrane by using the diagnosis developed method of these disorders.

\section{Materials and methods of research}

The REC diagnosis was carried out among 133 patients with CRPTB at the beginning of the intensive phase of antimycobacterial therapy during fibrobronchoscopy (FBS), provided there is a concomitant specific pathology of the mucous membrane (including its combination with non-specific endobronchitis). Average age of patients was $36.5 \pm 1.1$ years old. There were $89(66.9 \%)$ men and $44(33.1 \%)$ women.

The tracheobronchial tree diagnostic FBS with further study of the REC condition among patients suffering from CRPTB was carried out by V. M. Khlystun at Phthisiology and Pulmonology Department of Zaporizhzhia State Medical University in $\mathrm{Cl}$ "Zaporizhzhia Regional Antituberculous Clinical Dispensary".

The criteria for the patient inclusion in the research: presence of resistance of mycobacterium tuberculosis to antimycobacterial drugs, the presence of pathology of the bronchi mucous membrane, confirmed in the FBS. The exclusion criteria were severe concomitant diseases (HIVIAIDS, diabetes, etc.).

The condition of the bronchi mucous membrane was studied under the anesthetic anesthesia with the use of fibrotic bronchoscope, produced by Olympus Firm (Japan). The bronchial tree pathology was described under the classification of M. V. Shesterina, A. N. Kalyuk (1975).

The diagnosis of REC disorders in patients suffering from CRPTB with comorbidity of the bronchi mucous membrane was carried out as follows. Withdraw $0.5 \mathrm{ml}$ of heparin solution in 5000 units into a syringe, whereupon $4 \mathrm{ml}$ of a patient's venous blood is withdrawn into the same syringe. At the end of FBS, the patient is given $3.5-4.0 \mathrm{ml}$ of this heparinized blood in each bronchus. After 10-15 minutes after the FBS, the patient begins to collect sputum into the Falcon container for every 6 hours. The presence of hemoglobin $(\mathrm{Hb})$ is determined in each portion of the sputum with the help of "Azopiroma Sample-600/6" as follows. The patient's sputum from the container is poured into a $5 \times 5 \mathrm{~cm}$ gauze wipe, after which 4 drops of the reagent are applied to the sample to be examined. When a violet-lilac color appears in 1 minute, the test is considered to be positive, and in the absence of color, the test is considered to be negative, which indicates the absence of residual hidden blood. The research is completed after a qualitative response to the presence of $\mathrm{Hb}$ is not determined in the 3 subsequent sputum portions. At times of withdrawal, a conclusion is made on the state of REC. That is, the time for indicator full withdrawal in the normal time is 18 hours. The time for the indicator to be withdrawn is 36-48 hours in the $1^{\text {st }}$ stage of mucociliary inefficiency $(\mathrm{MCl})$, 54-66 hours in the $2^{\text {nd }}$ stage of $\mathrm{MCl}$, and $72-126$ hours in the $3^{\text {rd }}$ stage.

The research results were processed by modern methods of analysis on a personal computer using statistical software package Statistica ${ }^{\circledR}$ for Windows 6.0 (StatSoft Inc., AXXR712 D833214FAN5). The distribution of quantitative characteristics normality was analyzed using the Shapiro-Wilk test. The parameters were normally distributed. The comparison of the indicators in the groups was carried out by the Student's t-criterion.

\section{Results and discussion}

The condition study in patients suffering from CRPTB with comorbidity of the bronchi mucous membrane allowed to establish that the normal REC state at the beginning of the intensive phase of antimycobacterial therapy was determined in a small number of patients, namely 7 (5.3\%). The majority number of patients were diagnosed with REC with different degrees of severity - 126 (94.7\%): 68 patients $(51.1 \%)$ were diagnosed with $\mathrm{MCl}$ in the $1^{\text {st }}$ stage, $50(37.6 \%)$ persons in the $2^{\text {nd }}$ stage of $\mathrm{MCl}$ took the second place. The $3^{\text {rd }}$ stage of $\mathrm{MCl}$ was diagnosed only in 8 persons $(6 \%)$.

133 patients suffering from CRPTB were diagnosed with bronchial tuberculosis, 94 patients $(70.7 \%)$ of which had it in combination with nonspecific purulent endobronchitis.

Table 1 shows the dependence of $\mathrm{MCl}$ on the nature of the pathology of the bronchi mucous membrane. It was found that the incidence of REC among patients with concomitant bronchial tuberculosis, combined with nonspecific purulent endobronchitis, was 2.4 times higher than in bronchial tuberculosis - related patients: 94 (70.7 \%) versus $39(29.3 \%)(P<0,05)$. Furthermore, patients with only bronchial tuberculosis $\mathrm{MCl}$ had the $1^{\text {st }}$ and $2^{\text {nd }}$ stage (53.8 \% and $30.8 \%$, respectively), and the $3^{\text {rd }}$ stage of severity ( $8.5 \%$ ) was diagnosed with concomitant bronchial tuberculosis, combined with nonspecific purulent 
Table 1. $\mathrm{MCl}$ dependence on the nature of the bronchi mucous membrane pathology in patients with CRPTB at the beginning of intensive phase of antimycobacterial therapy

\begin{tabular}{|c|c|c|c|c|c|c|c|c|c|}
\hline \multirow[t]{3}{*}{ Indicator } & \multirow[t]{3}{*}{ Total } & \multicolumn{8}{|c|}{$\mathrm{MCl}$ stage } \\
\hline & & \multicolumn{2}{|c|}{ Norm } & \multicolumn{2}{|c|}{$1^{\text {st }}$ stage } & \multicolumn{2}{|c|}{$2^{\text {nd }}$ stage } & \multicolumn{2}{|c|}{$3^{\text {rd }}$ stage } \\
\hline & & abs. & $\%$ & abs. & $\%$ & abs. & $\%$ & abs. & $\%$ \\
\hline Bronchial tuberculosis & 39 & 6 & 15.4 & 21 & 53.8 & 12 & 30.8 & 0 & 0 \\
\hline Bronchial tuberculosis combined with nonspecific purulent endobronchitis & 94 & 1 & 1.3 & 47 & $50.0^{*}$ & 38 & $40.2^{*}$ & 8 & 8.5 \\
\hline - limited & 57 & 1 & 1.7 & 40 & $70.2^{* \#}$ & 14 & 24.6 & 2 & 3.5 \\
\hline - diffusive & 37 & 0 & 0 & 7 & 18.9 & 24 & $64.9^{* \#}$ & 6 & 16.2 \\
\hline
\end{tabular}

*: indicator reliable difference within the same group $(P<0.05)$; \#: indicator significant difference within the group $(P<0.05)$.

endobronchitis, with the prevalence of $\mathrm{MCl}$ of the $1^{\text {st }}$ stage of severity $(50.0 \%)$ and the $2^{\text {nd }}$ stage $(40.2 \%)$.

Analyzing nonspecific purulent endobronchitis by localization, the obtained data indicated that the $1^{\text {st }}$ stage $\mathrm{MCl}$ prevailed in the limited process, in comparison with the $2^{\text {nd }}$ and $3^{\text {rd }}$ stage $(70.2 \%$ versus $24.6 \%$ and $3.5 \%$, respectively; $\mathrm{P}<0.05)$ and by 3.7 times than in the $1^{\text {st }}$ stage, the diffusion process $(70.2 \%$ vs $18.9 \%, P<0.05)$. And the $2^{\text {nd }}$ stage $\mathrm{MCl}$ prevailed over the $1^{\text {st }}$ and $3^{\text {rd }}$ stages ( $64.9 \%$ vs $18.9 \%$ and $16.2 \% ; P<0.05)$ and by 2.6 times than in the limited process ( $64.9 \%$ vs $24.6 \%, P<0.05)$. Furthermore, the $3^{\text {rd }}$ stage $\mathrm{MCl}(16.2 \%$ vs $3.5 \%)$ was diagnosed 4.6 times more often in the diffuse endobronchitis, although not accurately.

Thus, a reliable dependence of $\mathrm{MCl}$ on the nature of the pathology of the bronchial mucosa among patients suffering from CRPTB at the beginning of intensive phase of antimycobacterial therapy, which manifested itself in the fact that the connection to the nonspecific purulent endobronchitis of concomitant bronchial tuberculosis leads to an increase of $\mathrm{MCl}$ stage severity due to its diffuse localization.

\section{Conclusions}

1. Respiratory epithelial clearance disturbances in $94.7 \%$, which were predominate with the $1^{\text {st }}$ and $2^{\text {nd }}$ stages of mucociliary inefficiency $(51.1 \%$ and $37.6 \%)$.

2. Mucociliary inefficiency depends on the bronchi mucous membrane pathology nature: the incidence of respiratory epithelial clearance in patients with concomitant bronchial tuberculosis in combination with the nonspecific purulent endobronchitis is 2.4 times higher than in those with bronchial tuberculosis - related concomitantly (70.7\% vs $29.3 \%)$.

3. The association of nonspecific purulent endobronchitis with concomitant bronchial tuberculosis leads to an increase in the mucociliary inefficiency degree of severity, due to its diffuse localization, where it is diagnosed more often than in a limited one, thus, mucociliary inefficiency of the $2^{\text {nd }}$ stage of severity is 2.6 times bigger $(64.9 \%$ vs $24.6 \%)$ and 4,6 times bigger in the $3^{\text {rd }}$ stage $(16.2 \%$ vs $3.5 \%$ ).

Prospects for further researches. With the help of the proposed method of diagnosis of REC disorders among patients suffering from CRPTB with concomitant bronchi mucosa pathology, an appropriate correction will be made, which will facilitate the full implementation of therapeutic measures for these patients and the treatment effectiveness increase.
Conflicts of Interest: authors have no conflict of interest to declare. Конфмікт інтересів: віАсутній.

Information about authors:

Raznatovska O. M., MD, PhD, DSc, Associate Professor, Professor of the Department of Phthisiology and Pulmonology, Zaporizhzhia State Medical University, Ukraine.

Khlystun V. M., Assistant of the Department of Phthisiology and Pulmonology, Zaporizhzhia State Medical University, Ukraine.

Відомості про авторів:

Разнатовська О. М., А-р меА. наук, Аоцент, професор каф. фтизіатрії і пульмонології, Запорізький державний медичний університет, Україна.

Хлистун В. М., асистент каф. фтизіатрії і пульмонології, Запорізький Аержавний медичний університет, Україна

Сведения об авторах:

Разнатовська Е. Н., А-р меА. наук, Аоцент, профессор каф. фтизиатрии и пульмонологии, Запорожский государственный медицинский университет, Украина. Хиыстун В. Н., ассистент каф. фтизиатрии и пульмонологии, Запорожский государственный медицинский университет, Украина.

Надійшла Ао редакції / Received: 11.09.2017

Після Аоопрацювання / Revised: 12.10.2017

Прийнято Ао Аруку / Accepted: 19.10.2017

\section{References}

[1] Zakharova, G. P., Yanov, Yu. K., \& Shabalin, V. V. (2010). Mukocilyarnaya sistema verkhnikh dykhatel'nykh putej [Mucociliary system of the upper respiratory tract]. Saint Petersburg: Dialog. [in Russian].

[2] Kobylyanskij, V. I. (2008). Mukocilyarnaya sistema. Fundamental'nye i prikladnye aspekty [Mucociliary system. Fundamental and applied aspects]. Moscow: BINOM. [in Russian].

[3] Zavalii, M. A. (2014). Morfogenez mercatel'nogo e'piteliya [Morphogenesis of ciliated epithelium]. Rynolohiia, 1, 38-49. [in Russian].

[4] Novikov, Yu. K. (2007). Mukociliarnyj transport, kak osnovnoj mekhanizm zashhity legkih [Mucociliary transport, as the main mechanism of lung protection]. Russkij medicinskij zhurnal, 5, 357. [in Russian].

[5] Chuchalin, A. G., Solopov, V. N., \& Kolganova, N. A. (1988). Diagnosticheskaya programma issledovaniya mukocilyarnogo transporta u bol'nykh khronicheskimi nespecificheskimi zabolevaniyami legkikh [Diagnostic program for the study of mucociliary transport in patients with chronic nonspecific lung diseases]. Problemy tuberkuleza, 8 , 13-16. [in Russian].

[6] Pertseva, T. A., Kireyeva, T. V., \& Gurzhiy, E. V. (2005). Novye podkhody $v$ issledovanii mukocilyarnogo klirensa u pacientov s bronkholegochnoj patologiej [New approaches in evaluation of mucociliary clearance in patients with bronchopulmonary diseases]. Ukrainskyi pulmonolohichnyi zhurnal, 4, 69-70. [in Ukrainian].

[7] Mall, M. A. (2008). Role of cilia, mucus, and airway surface liquid in mucociliary dysfunction: lessons from mouse models. J Aerosol Med Pulm Drug Deliv, 1, 13-24. doi: 10.1089/jamp.2007.0659. 